\title{
Bestemmelse av legemidler og rusmidler i hår
}

\author{
I de senere år har håranalyser fått økende aksept som et viktig supple- \\ ment til analyser med blod og urin som prøvemedium. Påvisning av \\ legemidler og rusmidler i blod og urin reflekterer som oftest et relativt \\ nylig inntak, mens stoffer i hår i større grad vil kunne avspeile et inntak \\ over tid. Håret vokser ca. $1 \mathrm{~cm}$ per måned, og segmentering av hårprø- \\ ven før analyse kan gi viktig informasjon om tidspunktet for inntak. \\ Håranalyser har en rekke kliniske anvendelsesområder, f.eks. i kon- \\ trollsammenheng og ved rettslige obduksjoner.
}

\section{Solfrid Hegstad}

solfrid hegstad@fhi.no

Lena Kristoffersen

Asbjørg S. Christophersen

Hassan Z. Khiabani*

Divisjon for rettstoksikologi

og rusmiddelforskning

Nasjonalt folkehelseinstitutt

Postboks 4404 Nydalen

0403 Oslo

\begin{abstract}
* Nåværende adresse:
Avdeling for legemiddelinformasjon

Statens legemiddelverk
\end{abstract}

Det gjøres stadig flere analyser for å avsløre bruk av legemidler og rusmidler. Den teknologiske utvikling muliggjør nå analyse av slike stoffer i medier hvor det tidligere var begrensede muligheter for å finne spor, f.eks. hår. Håranalyser brukes internasjonalt i stigende grad i tilfeller hvor det er ønskelig å øke tidsvinduet for påvisning betydelig (1). Resultater fra håranalyser kan avspeile en eksponering over tid og vil derfor øke tidsvinduet fra timer/dager/uker til måneder og år. Det kan dessuten være mindre krenkende å ta en slik prøve enn prøvetaking ved hjelp av andre metoder, tidspunktet for prøvetaking er ikke kritisk og oppbevaringen av prøven er enkel. Det som setter begrensninger i påvisningsvinduet er hovedsakelig lengden på håret og hyppighet og mengde av stoffinntak.

Vi vil her gi en oversikt over fordeler og begrensninger ved å analysere ulike legemidler og rusmidler i hår. Eksempler på kliniske anvendelsesområder er hentet fra internasjonale studier. Egne erfaringer omtales også.

\section{Legemidler og rusmidler i hår}

Legemidler og rusmidler og deres metabolitter tas opp $\mathrm{i}$ håret fra blodet $\mathrm{i}$ hårsekken og bindes i håret etter hvert som det vokser.
Hodehåret vokser ca. $1 \mathrm{~cm}$ per måned. Hårveksten kan deles i tre ulike faser eller sykluser (1) - $\mathrm{i}$ anagenfasen vokser håret mest aktivt, i katagenfasen eller regresjonsfasen slutter det å vokse og i telogenfasen løsner hårroten og håret faller av. Hastigheten på hårveksten er forskjellig fra individ til individ, i tillegg er det variasjon hos det samme individet avhengig av området håret vokser på. Det er f.eks. hastighetsforskjell på veksten i hodebunnen versus veksten i armhulen hos en person. Imidlertid er det gjort undersøkelser som viser at variasjonen i hårveksthastighet er minst på toppen av bakhodet.

Fargestoffet i håret er melanin, som består av to typer - feomelanin og eumelanin. Eumelanin gir fargen svart/brunt, feomelanin rødt/lyst hår. Mange stoffer har en høyere affinitet til eumelanin enn til feomelanin, det vil derfor være en høyere konsentrasjon av disse stoffene $\mathrm{i}$ hår som er svart/ brunt enn i rødt/lyst hår (2). I tillegg til sol og hårvask reduseres konsentrasjonen av stoffene ved behandling av håret, f.eks. permanent eller bleking. Bindingen mellom håret og stoffene blir også dårligere etter hvert som håret eldes (3). For enkelte stoffer kan tidsvinduet $\mathrm{i}$ hår være opptil ett år. Tidsvinduet avhenger av konsentrasjonen av inkorporert stoff, hårets lengde, behandling av håret og metodens sensitivitet. Stoffer funnet $\mathrm{i}$ hår kan bekrefte inntak, men ikke hvor mye som er inntatt.

\section{Analyse}

Hvordan hårprøven blir tatt er viktig for resultatet av analysen. Figur 1 viser hvordan prøven bør tas. Hodehåret er det enkleste alternativet for å få nok hår. For å kunne angi tidspunktet for inntak segmenteres håret i 1-2 cm lange biter før analyse. Segmentering av håret kan gi informasjon ved bestemmelse av tidspunkt for inntak og med høy grad av sannsynlighet angi i hvilken måned stoffet er inntatt.
Håret kan kontamineres via luft, svette og hudfett. Det er også mulig at stoffer kan påføres håret ved kontakt med f.eks. kontaminerte pengesedler eller tekstiler. I tillegg opptas stoffene lettere i behandlet og skadet hår enn i intakt hår. For å minimere ekstern kontaminering er det viktig at håret vaskes før analyse. Det er utviklet vaskeprosedyrer for dette formålet, der også vaskevannet analyseres for å avdekke om stoffet er påført håret eksternt. Måling av metabolitten av et stoff kan øke sikkerheten for at stoffet målt i håret ikke er en ekstern kontaminering. Imidlertid er det vist at metabolitter for enkelte stoffer, f.eks. kokain, dannes også etter opptak i håret (1). Usikkerhet rundt eventuell ekstern kontaminering må tas med i vurderingen i hver enkelt sak ved positive funn.

Society of hair testing ble grunnlagt i 1995 og publiserte i 2004 retningslinjer for prøvetaking, dekontaminering, behandling av prøven og kriterier for positive resultater. Ved bestemmelse av legemidler og rusmidler anvendes immunologiske metoder, gasskromatografi med massespektrometri og væskekromatografi med massespektrometri $(1,3-5)$.

Ved Nasjonalt folkehelseinstitutt har vi utviklet en kromatografisk screeningmetode (væskekromatografi med massespektrometri) for rusmidler i hår der 22 stoffer kan bestemmes (nikotin, cotinin, amfetaminer, metamfetamin, MDMA, morfin, 6-MAM, kodein, kokain, benzoylecgonin, 7-aminonitrazepam, 7-aminoklonazepam, 7-aminoflunitrazepam, oksazepam, diazepam, alprazolam, metadon, buprenorfin, meprobamat, karisoprodol, zopiklon, zolpidem). Metoden er validert og publisert (6).

\section{Anvendelsesområder}

Kliniske anvendelsesområder for håranalyse har fått stor oppmerksomhet internasjonalt - av flere grunner. Forskjellige stoffer med metabolitter lagres $i$ hårskaftet etter som håret vokser. Dette gir økt tidsvindu for stoffdeteksjon i forhold til analyser i blod og urin. Hårprøvetakingen er enkel og ikke-invasiv, og det er mulig å få bekreftet resultatene ved ny prøve. Stoffene $i$ håret er relativt stabile, dette stiller betydelig mindre krav til langvarig lagring av prøvene. Det er lav risiko for smitteoverføring ved prøvetaking og liten fare for manipulering av prøven. I det følgende nevnes noen konkrete kliniske områder hvor håranalyser er utført. 


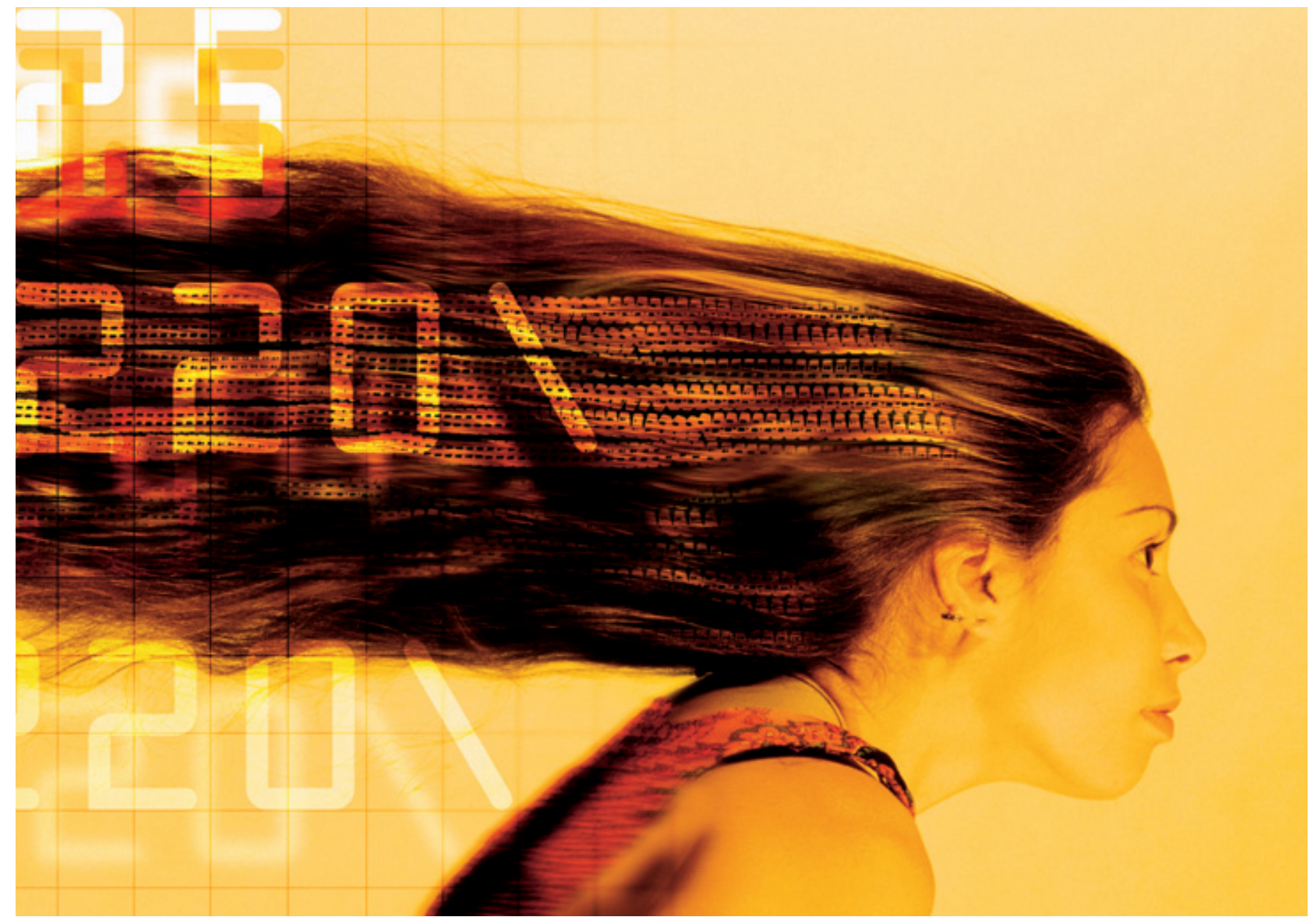

\section{Psykiatriske pasienter}

Bruk av legemidler med ruspotensial og illegale rusmidler er relativt vanlig hos psykiatriske pasienter (7). Hos disse kan håranalyse være nyttig når det er mistanke om at misbruk kan være en medvirkende årsak til en psykisk forstyrrelse. Håranalyser kan gi informasjon om et eventuelt misbruk det ikke er opplyst om eller kan brukes for å avdekke underrapportering. Eksempelvis ble en prøve sendt til Folkehelseinstituttet fra en psykiatrisk avdeling ved et sykehus i Norge for å bekrefte eller avkrefte mistanke om bruk av amfetamin og benzodiazepiner. Hårbunten ble delt inn i segmenter på $1 \mathrm{~cm}$. Det var ingen spor av amfetamin eller benzodiazepiner i segmentene. Zopiklon ble imidlertid påvist $\mathrm{i}$ de fleste segmentene. Håranalysen kunne i dette tilfellet indikere at hyppig bruk av amfetamin og benzodiazepiner ikke hadde forekommet og kunne således være til hjelp i diagnostiseringen av pasienten.

\section{Oppfølging av rusmisbrukere}

I kontroll av rusmisbrukere som er i et behandlingsopplegg, er det vanlig å benytte urin som analysemedium. For urin, som kun viser et relativt nylig inntak, må det tas prøver 1-2 ganger per uke. For hår er ikke prøvetakingstidspunktet kritisk, og antall prøver kan reduseres fra 1-2 per uke til 2-3 i halvåret (forutsatt langt nok hår). I tillegg kan medikamentbruken før behandling bestemmes ved å ta hårprøver før behandlingsstart. Bestemmelse av misbruksstoffer i hår kan dermed si noe om misbruk og kan brukes til diagnostisk hjelp. I et samarbeidsprosjekt mellom Folkehelseinstituttet og Senter for rus og avhengighetsforskning er hårprøver fra rusmisbrukere under behandling med naltrekson blitt benyttet til dette formålet. Resultatene viser et samsvar på $86 \%$ mellom opioider (morfin, 6-MAM, kodein, metadon og buprenorfin) målt $\mathrm{i}$ håret $\mathrm{og}$ selvrapportering (8).

\section{Postmortal rettstoksikologisk analyse}

Hårprøver tatt ved obduksjon kan være et nyttig hjelpemiddel til fastsettelse av dødsårsak (1). Håranalyser er generelt ikke egnet til å avdekke død forårsaket av en akutt forgifting, men resultater fra håranalyser kan indikere et eventuelt kronisk misbruk før dødstidspunktet. Dette er informasjon som kan være med på å støtte diagnostisering av dødsårsaken. I overdosedødsfall med heroin eller metadon kan håranalyser si noe om bruken av disse stoffene i perioden forut for dødstidspunktet. Ved postmortal rettstoksikologisk analyse av blod og urin påvises ikke sjelden lave konsentrasjoner av f.eks. opioider. Et lavt forbruk av opioider før dødsfallet kan forklare manglende evne til å tåle den aktuelle dosen målt i f.eks. blod. Håranalyser kan gi verdifull informasjon om utvikling av toleranse i slike saker.

\section{Oppfølging av rusdømte bilførere}

I Norge vil personer som er dømt for bilkjøring i påvirket tilstand ofte miste retten til å føre motorvogn for en periode på opptil to år. I slike tilfeller kreves det nesten alltid ny førerprøve. I Tyskland og Italia inngår håranalyser som del av prosedyren for at personer som har tapt retten til å føre motorvogn pga. påvirket kjøring kan få tilbake førerkortet (1). I Tyskland tas en hårprøve på $6 \mathrm{~cm}$, som dekker de siste seks måneder. Negativ prøve gir holdepunkter for at føreren har greid å holde seg rusfri i den aktuelle perioden, et krav for å få igjen førerkortet. På denne måten kan et eventuelt vedvarende misbruk avdekkes, noe som fører til at vedkommende ikke får lov til å kjøre bil igjen. Det har vært diskutert om noe liknende skulle innføres i Norge. Et slikt tiltak kunne sannsynligvis bedret sikkerheten - ved at de som ville ha tilbake førerkortet, måtte bevise at de greide å holde seg rusfrie i en lengre tidsperiode. 


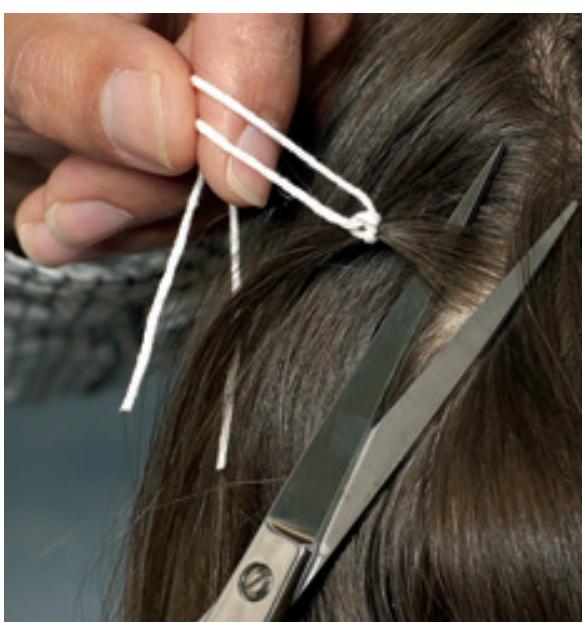

Figur 1 Prøvetaking av hår

\section{Oppsummering}

Håranalyser kan påvise inntak av ett eller flere rusmidler og legemidler. Håret som medium kan dekke et tidsvindu på flere måneder, opptil år - den begrensende faktor er fortrinnsvis mengde hår og lengde på håret. Segmental håranalyse gir mulighet til å si om det var et inntak i en begrenset periode eller inntak over flere måneder. Håranalyser har absolutt en plass i en rettstoksikologisk avdeling fordi påvisningsvinduet er unikt, først og fremst i en rekke kliniske problemstillinger og også $\mathrm{i}$ enkelte rettstoksikologiske tilfeller.

Oppgitte interessekonflikter: Ingen

\section{Litteratur}

1. Pragst F, Balikova MA. State of the art in hair analysis for detection of drug and alcohol abuse. Clin Chim Acta 2006: 370: 17-49.

2. Kronstrand R, Scott K. Drug incorporation into hair. I: Kintz P, red. Analytical and practical aspects of drug testing in hair. Boca Raton, FL: CRC Press, 2007: 1-23.

3. Pragst F, Rothe M, Spiegel $K$ et al. Illegal and therapeutic drug concentration in hair segements - a timetable of drug exposure. Forensic Sci Rev 1998; 10: 81-111.

4. Kronstrand R, Nystrom I, Strandberg J et al. Screening for drugs of abuse in hair with ion spray LC-MS-MS. Forensic Sci Int 2004; 145: 183-90.

5. Shen M, Xiang P, Wu H et al. Detection of antidepressant and antipsychotic drugs in human hair. Forensic Sci Int 2002; 126: 153-61.

6. Hegstad S, Khiabani HZ, Kristoffersen L et al. Drug screening of hair by liquid chromatography tandem mass spectrometry. J Anal Toxicol 2008; 32: $364-72$.

7. Mordal J, Bramness JG, Holm B et al. Drugs of abuse among acute psychiatric and medical admissions: laboratory based identification of prevalence and drug influence. Gen Hosp Psychiatry 2008; 30: 55-60.

8. Kunoe N, Lopmaier P, Vederhus R et al. A randomized prospective trial of naltrexone implants after inpatient treatment for opioid dependence. Br J Psychiatry 2008; akseptert for publisering. 